\title{
Yüksek rakımda yetiştirilen bazı sofralık üzüm çeşitlerinin fenolojik ve kalite özellikleri
}

\section{Phenology and quality characteristics of table grape cultivars grown in high elevation}

\section{H. İbrahim UZUN ${ }^{1}$, Bircan KILINÇ ${ }^{2}$ i]}

${ }^{1}$ Akdeniz Üniversitesi, Ziraat Fakültesi, Bahçe Bitkileri Bölümü, Antalya, Türkiye

${ }^{2}$ T.C. Tarım ve Orman Bakanlığı

Sorumlu yazar (Corresponding author): H. İ. Uzun, e-posta (e-mail): uzun@akdeniz.edu.tr

Yazar(lar) e-posta (Author e-mail): bircantr@gmail.com

\section{MAKALE BİLGİSİ}

Alınış tarihi 20 Şubat 2020

Düzeltilme tarihi 27 Ekim 2020

Kabul tarihi 27 Ekim 2020

\section{Anahtar Kelimeler:}

Ekoloji

Vinifera

Sofralık üzüm

Yayla bağc1lığ 1

\section{ÖZ}

Bu çalışma, 2018 yılında Kahramanmaraş'ın Göksun ilçesinde (bağın rakımı: $1420 \mathrm{~m}$ ) gerçekleştirilmiş̦tir. Araştırmada, Kabarcık, Kirkit ve Yalova İncisi sofralık üzüm çeşitleri incelenmiștir. Ceșitlerin fenolojik özelliklerinin yanında, salkım ve tane özellikleri ölçülmüştür. İncelenen çeşitler arasında en erken, Yalova İncisi çeşidi olgunlaşmışıtr. Uyanmadan olgunlaşmaya kadar geçen en kısa süre, Yalova İncisi'nde gerçekleşmiștir (138 gün). Çeşitler nisan sonunda uyanmış ve haziran ortasında çiçeklenmiştir. Yalova İncisi'nin hasat edildiği 5 Eylül 2018 tarihinde tanelerde \%18.8 SÇKM ve \%0.52 asit tespit edilmiştir. Yerel çeșitlerden Kirkit, ekim ayı başında olgunlaşmıștır. Bu çeșitte \%22.8 SCCKM ve \%0.56 asitlik belirlenmiş ve olgunluk indisi 34.03 olarak hesaplanmıştır. Fakat Kabarcık bu tarihte tam olarak olgunlaşamamış ve tanelerde \%13.1 SÇKM belirlenmiş ve çeşidin bu tarihtek olgunluk indisi 14.24 olarak hesaplanmıştır. Bu zamanda yörede don olaylarının meydana gelmesi nedeniyle, Kabarcık çeşidi erken hasat edilmek zorunda kalınmıştır. En büyük salkımlar Kabarcık'ta (583.99 g), en iri taneler ise Yalova İncisi'nde (4.85 g) saptanmıștır. Tane eti sertliği bakımında Kirkit ( $2.91 \mathrm{~N}$ ) diğerlerine göre daha sert, tanenin saptan kopma kuvveti ise Kabarcık $(1.88 \mathrm{~N})$ çeșidinde daha kuvvetli bulunmuştur. en fazla çekirdek Kabarcık çeşidinde (3.2 adet tane $\left.{ }^{-1}\right)$ saptanmıştır. İncelenen çeşitlerden Yalova İncisi ve Kirkit'in yöre için uygun olduğu fakat Kabarcık çeşidinin yöre de yetiştiriciliğinin sonbahardaki erken donlar nedeniyle riskli olduğu saptanmıştır. Yörede, diğer erkenci ve çok erkenci üzüm çeşitlerinin adaptasyon çalışmalarının yapılmasında fayda vardır.

\section{ARTICLE INFO}

Received 20 February 2020

Received in revised form 27 October 2020

Accepted 27 October 2020

\section{Keywords:}

Ecology

Vinifera

Table grape

Highland viticulture

\begin{abstract}
This study was carried out in a vineyard located in Göksun town of Kahramanmaraş (elevation: $1420 \mathrm{~m}$ ) in 2018. Yalova İncisi, Kabarcık and Kirkit grape cultivars were investigated for date of phenological stages and fruit characteristics. Yalova İncisi was the earliest matured cultivar. The shortest period of time from bud-burst to maturing was observed in Yalova Incisi (138 days). Bud-burst happened at the end of April and flowering was observed in mid-June. Clusters of Yalova Incisi were harvested at $18.8 \%$ brix and $0.52 \%$ acidity on September 5. Kirkit matured in early October at $22.8 \%$ brix and $0.67 \%$ acidity with maturity index was 34.03 . However, Kabarck was not fully matured at this date and maturity index was measured as 14.24. Because of the occurrence of early frosts in autumn, Kabarcik had to be harvested earlier on the beginning of October. The largest clusters were found in Kabarckk $(583.99 \mathrm{~g})$ and the largest berries in Yalova Incisi $(4.85 \mathrm{~g})$. In terms of berry firmness, Kirkit $(2.91 \mathrm{~N})$ was found to be stronger than the others, and berry detachment force of the berries were found to be strongest in the Kabarcik $(1.88 \mathrm{~N})$. The highest number of seeds per berry was measured in Kabarcik $\left(3.2\right.$ piece berry $\left.^{-1}\right)$. Yalova Incisi and Kirkit cultivars were suitable for the region but cultivation of the Kabarcik variety was risky due to early frosts in autumn. It is recommended that adaptation studies of other early and very early grape cultivars should be carried out in that region.
\end{abstract}




\section{Giriş}

Ülkemizde yüksek rakımlarda yetiştirilen üzüm çeşitleri hakkında temel bilgiler yok denecek kadar azdır. Ülkemizde yetiştirilen üzümler için son turfanda dönemi olan ekim ayında geçci çeşitlerin yetiştirilmesi, üzümlerin yüksek fiyatla satılması imkanı sağlar.

Asmaların vejetasyon periyodundaki hayat döngüsü; uyanma, çiçeklenme, ben düşme, olgunlaşma ve yaprak dökümü gibi fenolojik safhaları içermektedir (Uzun 2004). Vejetasyon dönemi içerisinde yer alan fenolojik safhalarının başlangıç tarihleri asma çeşitleri arasında farklılık göstermekte ve çeşitlerin sıralaması safhadan safhaya değişebilmektedir. Başka bir deyişle, diğer çeşitlere nazaran daha erken bir tarihte uyanan bir asma çeşidinin diğer çeşitlerden daha erken bir tarihte hasat olgunluğuna erişeceğinin bir göstergesi olarak yorumlamak doğru bir yaklaşım değildir (Gürsöz ve Ergenoğlu 1987).

Karaçalı (2006), \% şeker miktarının \% asit miktarına oranlanması ile hesaplanan olgunluk indisinin en kullanışlı hasat ölçütü olduğunu belirtmiştir. SÇKM, pH ve asitlik değerlerinin olgunluğun tespit edilmesinde önemli etkenler olduğu, olgunluğun "amaca uygun bir olgunluk indisiyle" tespit edilmesi gerektiği belirtilmiştir (Gürsöz ve Ergenoğlu 1987). Hasat olgunluğunun tespit edilmesinde baz alınacak olgunluk indisinin erkenci çeşitlerde 20, orta mevsim çeşitlerde 25 , geçci özellik gösteren çeşitlerde ise 30-35 değerlerinde olması yeterli olacağı ifade edilmiştir. Ayrıca, üzüm çeşitlerinde, SÇKM değerinin erkenci çeşitler için \%12-13, diğer çeşitlerde ise \%16-17 değerlerinde bulunmasının hasat tarihinin belirlenmesinde yeterli olacağı bildirilmiştir (Karaçalı 2006). Diğer taraftan Uzun ve ark. (1995), sıcaklığın üzümün yapısında bulunan asitlerin parçalanmasında etkili olduğunu ve bu olayın sıcak iklim bölgelerinde daha hızlı gerçekleştiğini bildirmişlerdir. $\mathrm{Bu}$ nedenle aynı üzüm çeşidine ait olgunluk indisi değerinin, üzüm yetiştiriciliğinin yapıldığ 1 farklı bölgelerde sıcaklık değişimine bağlı olarak, farklı kuru madde ve asit değerinde olabileceğini bildirmişlerdir. Bir başka deyişle farklı sıcaklık değerlerinde yetiştirilen üzüm çeşidinin $\%$ asit değerinin sıcaklıkla ters orantılı olarak değişeceğini bildirmişlerdir. Ayrıca Ağaoğlu (2002) tarafından, sürgün gelişiminin çeşit özelliklerine bağlı olarak farklı optimum sıcaklık değerlerine göre değişiklik gösterdiği ve sürgün gelişiminin genel olarak $25-30^{\circ} \mathrm{C}$ aralığında gerçekleştiği belirtilmiştir. Hava sıcaklığının $15^{\circ} \mathrm{C}$ 'nin altında olması durumunda sürgün gelişimi olumsuz etkilendiği ve sürgün gelişimi için alt sınırın $8^{\circ} \mathrm{C}$ olarak kabul edildiği ifade edilmiştir.

Yücel (2009), Adana ili Ceyhan ilçesinde 2009 yılında 4 köyde 8 farklı bağ alanında Yalova İncisi, Early Cardinal, Trakya İlkeren çeşitlerinin yöre koşullarında pomolojik ve fenolojik özelliklerini incelemiştir. Yalova İncisi çeşidinin fenolojik safhalarından; gözlerin uyanmasının 10-13 Mart, tam çiçeklenmenin 26 Nisan-2 Mayıs, ben düşmenin 8-15 Haziran, olgunluk 6-13 Temmuz tarihleri arasında gerçekleştiği saptanmıştır. Meyveyle ilgili analizlerde ise; salkım ağırlı̆̆ 338.30-477.67 g, SÇKM \%11.67-13.93, asitlik \%0.31-0.37 olarak ölçülmüştür.

Aktürk (2017), Antalya ekolojisinde farklı 32 üzüm çeşidinin fenolojik ve meyve özelliklerinin yanı sıra bunların değişik ekolojilere uygunluklarını inceleyen bir çalışma yürütmüştür. Söz konusu çalışmada hasat tarihindeki ölçümlerde Yalova İncisi çeşidinde; SÇKM \%12.6, asitlik $\% 0.44, \mathrm{pH} 3.64$, olgunluk indisi 28.4 , ortalama salkım ağırlığ
$626.5 \mathrm{~g}$, ortalama salkım eni $15.83 \mathrm{~cm}$, ortalama salkım boyu $18.75 \mathrm{~cm}$ olarak belirlenmiştir. Aynı çeşitte 2017 yılında fenolojik safhaların meydana geliş tarihleri; uyanma 22 Mart, tam çiçeklenme 13 Mayıs, ben düşme 08 Haziran, olgunlaşma 07 Temmuz olarak not edilmiştir. Aynı çalışmada Kabarcık çeşidinin hasat tarihinde tanelerdeki; SÇKM \%14.6, asitlik $\% 0.55$, pH 3.61, olgunluk indisi 26.3 olarak belirlenmiştir. Hasat edilen salkımlarda; salkım ağırlığı 426.65 g, salkım eni $15.33 \mathrm{~cm}$, salkım boyu $18.5 \mathrm{~cm}$ olarak ölçülmüştür. Kabarcık çeşidinin fenolojik safhalarından uyanma 12 Mart, tam çiçeklenme 13 Mayıs, ben düşme 2 Temmuz ve olgunlaşma 8 Ağustos tarihlerinde gerçekleşmiştir.

Gazioğlu Şensoy ve Balta (2010), 420A ve 110R anaçları üzerine aşılı Yalova İncisi ve diğer 5 üzüm çeşidinin Van ekolojisine adaptasyonları ile ilgili üç yıllık bir araştırma yürütmüşlerdir. Söz konusu çalışmada, 110R anacına aşılı Yalova İncisi çeşidinin salkım eni 9.33-13.75 cm, salkım boyu 22.00-24.25 cm, tane ağırlı̆̆ $5.07-6.31 \mathrm{~g}$, tane eni $21.00-23.30$ $\mathrm{mm}$, tane boyu $25.00-27.10 \mathrm{~mm}$, tanedeki çekirdek sayıs1 1.40-2.50 adet, pH 3.64-3.70, SÇKM \%17.21-16.66, titre edilebilir asitlik \%0.41-0.51 aralığında olduğu saptanmıştır. Aynı çeşidin 420A anacına aşılı asmalarında ise; salkım eni 12.00-13.47 cm, salkım boyu 21.00-24.66 cm, tane ağırlığ1 4.40-6.21 g, tane eni 18.40-24.80 mm, tane boyu 22.40-28.00 mm, tanedeki çekirdek sayıs1 1.35-2.57 adet, $\mathrm{pH}$ 3.62-3.71, SÇKM \%16.50-18.15, titre edilebilir asitlik \%0.49-0.58 aralığında olduğu ölçülmüştür. Asma anaçları kıyaslandığında, 420A'nin 110P'e göre Yalova İncisi çeşidinde daha olumlu sonuçlar verdiği bildirilmiş ve Van ekolojisinde Yalova İncisi çeşidinin ticari amaçlı yetiştiriciliğinin önerilebileceği belirtilmiştir.

Yalınkılıç (1996) tarafindan, Kahramanmaraş bağcılığı ve üzüm çeşitlerinin fenolojik gelişimleri üzerine ilçeler bazında 33 çeşit üzüm ile yürütülen bir araştırmada; Yalova İncisi, Kabarcık ve Kirkit çeşitlerinin fenolojik gelişim zamanları bildirilmiştir. Göksun ilçesinde Kabarcık çeşidinin 20 Eylül, Kirkit çeşidinin ise 30 Eylül tarihlerinde olgunlaştığı belirtilmiştir.

$\mathrm{Bu}$ çalışmada, yörede bağcılığın yapıldığı en yüksek rakımlardan biri olan Kahramanmaraş ilinin Göksun ilçesinde (Bağın rakımı: $1420 \mathrm{~m}$ ) yetiştirilen bazı üzüm çeşitlerinin fenolojik özellikleri ile hasat tarihindeki fiziksel ve biyokimyasal meyve özellikleri hakkında bilgi vermek amaçlanmıştır.

\section{Materyal ve Yöntem}

\subsection{Materyal}

$\mathrm{Bu}$ araştırma, Kahramanmaraş İli, Göksun İlçesi, Kanlıkavak Mahallesinde bulanan bir bağ alanında, 2018 y1lında yürütülmüştür. Araştırmanın yürütüldüğü bağ alanının İlçe merkezine uzaklığı yaklaşık olarak $15 \mathrm{~km}$ olup, deniz seviyesinden yüksekliği yaklaşık 1420 m'dir. Bağ, yaklaşı \%8 eğimli bir alanda kurulu olup, T şeklinde telli terbiye sistemi ve damlama sulama sistemi mevcuttur. Budama, sulama ve ilaçlama işlemleri çiftçi tarafından yapılmıştır. Bazı asmalarda az da olsa külleme zararı görülmüştür. Fakat salkım örnekleri hastalıksız asmalardan alınmıştır. Bağ, 2016 yılı Mart ve 2017 Nisan ayında (2017 yılında budamadan sonra) soğuktan etkilenmiştir. Üzüm örneklerinin alındığı asmalar 6 yaşındadır. Araştırma materyali olarak, 1103 Paulsen anacı aşılı; Kabarcık, Kirkit ve Yalova İncisi isimli 3 adet sofralık üzüm çeşidi kullanılmıştır. Kabarcık ve Kirkit çeşitleri yerel üzüm 
çeşitleridir. Yöredeki daha düşük rakımlı bağlarda yaygın olarak yetiştirilmektedir. Yalova İncisi ise Yalova Atatürk Bahçe Kültürleri Araştırma Enstitüsü tarafından melezleme ile elde edilmiş çok erkenci bir çeşittir. Çeşitlerin tümü beyaz renkli ve çekirdekli tanelere sahip olup, sofralık olarak değerlendirilmektedir. Yerel çeşitler yörede tanınmış olması; diğer çeşit ise çok erkenci olması ve çok yüksek rakımda yetişme potansiyelinin fazla olabileceği düşüncesiyle seçilmiştir. Çalışma her bir çeşide ait 5 asmada yürütülmüştür.

Araştırmada kullanılan sıcaklık rasatları, Temurağa Mahallesinde İlçe Tarım ve Orman Müdürlüğü tarafindan kurulan ve verilerin düzenli olarak kontrol edildiği Erken Uyarı Sisteminden alınmıştır. Temurağa Mahallesi araştırmanın yürütüldüğü bağ alanına yaklaşık $3 \mathrm{~km}$ uzaklıktadır. Kıraç (2016) tarafından ifade edildiği şekilde, 1978-2012 yılları arasında Göksun Meteoroloji Müdürlüğünden alınan rasat verilerine göre, 1978-2010 yılları arasında (2010 yılı dâhil) aylık ortalama hava sıcaklığı; mayıs-ekim döneminde $10^{\circ} \mathrm{C}$ ' nin üstünde ölçülmüştür.

\subsection{Yöntemler}

\subsubsection{Fenolojik safhaların gözlenmesi}

Araştırmada; uyanma, tam çiçeklenme, ben düşme ve olgunlaşma safhaları belirlenmiştir. OIV tarafindan bildirilen kriterler esas alınarak, 1 Nisan itibari ile düzenli aralıklarla bağ ziyaret edilmiş olup, yapılan gözlemler sonucu fenolojik safhaların oluş tarihleri kayıt altına alınmıştır (OIV 2001). Ben düşme tarihinden 15 gün sonra belirli aralıklarla asmalardan alınan tane örneklerinden elde edilen şırada, çeşitlerin olgunluk indisleri takip edilmiş ve hasat tarihleri buna göre belirlenmiştir.

Gözlerde uyanma; yaprak ucunun yeşil renginin tomurcukların \%50'sinde görüldüğü tarih olarak belirlenmiştir. Tam çiçeklenme, bir asmadaki çiçeklerin \%50'sinin açtığı tarih olarak kayıt edilmiştir. Ben düşme tarihi, bir asmadaki salkımların \%50'sinde tanelerin yeşil renginin olgunluk dönemi rengine dönmeye başladığı zaman olarak kabul edilmiştir. Olgunluk; her bir çeşidin olgunluk indisi (\%SÇKM \%Asit $\left.{ }^{-1}\right)$ değerinin 25-35 arasındaki bir değere ulaştı̆̆ 1 zaman, hasat tarihi olarak kabul edilmiştir (Uzun 2004).

\subsection{2. Çeşitlerin pomolojik özellikleri}

Salkım ölçümleri, hasattan sonra her bir çeşidi temsil edecek özellikte olan ve her bir asmadan birer adet tesadüfen seçilen toplam 5 adet sağlam ve sağlıklı salkımlarda gerçekleştirilmiştir. Tane özelliklerinin saptanması, salkımların orta kısımlarından 5er tane olarak tesadüfen alınan toplam 25 adet üzüm tanesinde, OIV ve Cemeroğlu tarafindan bildirilen yöntemler esas alınarak yapılmıştır (OIV 2001; Cemeroğlu 2010). Titre edilebilir asit miktarları, titrasyon yöntemiyle $\mathrm{NaOH}$ ve fenol fitaleyn kullanılarak; $\mathrm{pH}$ analizleri, dijital göstergeli pH metre kullanılarak; SÇKM ölçümleri ise \%0-32 Brix okuma aralığına sahip el refraktometresi kullanılarak gerçekleştirilmiştir. Salkım ağırlığı, çeşidi temsil edecek nitelikteki salkımların hassas terazide tartılmasıyla, her bir çeşit için ayrı ayrı saptanmış ve gram (g) cinsinden belirtilmiştir. Salkım eni ve boyu; şerit cetvel yardımıyla her bir çeşidi temsil eden salkımların en ve boyu, OIV (2001) tarafindan belirtildiği şekilde mm olarak ölçülmüştür. Tane ağırlığı, toplam 25 adet tanenin hassas terazide tartılması ve bunun ortalamasının alınmasıyla belirlenmiş ve $\mathrm{g} \operatorname{tane}^{-1}$ olarak verilmiştir. Tane eni ve boyu OIV (2001) tarafindan belirtildiği şekilde dijital bir kumpas yardımıyla ölçülmüş ve milimetre $(\mathrm{mm})$ olarak ifade edilmiştir. Tane hacmi; salkımlardan alınan toplam 25 adet üzüm tanesinin taşırma kabına konulması sonucunda ve kaptan taşan suyun mililitre $(\mathrm{ml})$ cinsinden ölçülmesiyle saptanmıştır. Daha sonra tanenin birim hacmi $\mathrm{ml} /$ tane $^{-1}$ olarak hesaplanmıştır. Çekirdek sayısı; toplam 25 adet üzüm tanesinin çekirdekleri ayrılıp sayılarak toplam çekirdek sayısı belirlenmiş ve bu toplamın ortalaması alınarak, üzüm tanesi başına çekirdek sayısı adet $\operatorname{tane}^{-1}$ şeklinde belirlenmiştir. Üzüm şırasında suda çözünebilir kuru madde (SÇKM) miktarı el refraktometresi yardımıyla \% olarak ölçülmüştür. Titre edilebilir asitlik (TEA); Kolorimetrik titrasyon yöntemi kullanılarak, Cemeroğlu (2010) tarafından belirtildiği şekilde, tartarik asit cinsinden \% olarak hesaplanmıştır. $\mathrm{pH}$ analizi, şırada dijital $\mathrm{pH}$ metre ile ölçülmüştür (Cemeroğlu 2010). Tanenin saptan ayrılma kuvveti (SAK); Chatillon marka, 0,05 $N$ hassasiyetli dijital göstergeli dinamometre ile Newton $(\mathrm{N})$ cinsinden ölçülmüştür. Tane eti sertliği (TES); Chatillon marka, dinamometre ile Newton (N) cinsinden ölçülmüştür. Dinamometrenin ucu, ölçüme uygun bir aparat ile modifiye edilmiştir. Tanelerin uç kısmı bisturi ile kabuk kısmının ince bir şekilde kesilmesinden sonra ölçüm yapılmıştır. Ölçümler esnasında dinamometrenin uç kısmı çekirdeklere ulaşmamıştır.

\subsection{3. İstatistikî analiz}

Deneme, üretici bağında gerçekleştirildiğinden ve kullanılan çeşitlere ait asmaların dikiminin belirli bir deneme desenine göre planlanmamış olması nedeniyle, parametrelere ait veriler, ortalama ve standart sapma değerleri olarak verilmiştir.

\section{Bulgular}

\subsection{Fenolojik bulgular}

Bağda yapılan gözlemlerde, Kirkit ve Yalova İncisi çeşitlerinin 20.04.2018 tarihinde uyandığ 1 görülmüştür. Kabarcık çeşidinde ise uyanma bir gün önce gerçekleşmiştir. Böylece tüm çeşitlerde uyanma safhasının nisan ayının ikinci yarısında meydana geldiği belirlenmiştir. Tam çiçeklenme 1417 Haziran tarihleri arasında gerçekleşmiştir. Gözlem yapılan çeşitlerde ben düşme safhasının ağustos ayının ikinci yarısında gerçekleştiği tespit edilmiştir. Ben düşme safhası, ilk olarak Yalova İncisi (15.08.2018) çeşidinde gerçekleşirken, en son Kabarcık (28.08.2018) çeşidinde saptanmıştır. Uyanma safhasından ben düşme safhasına kadar geçen süre; Yalova İncisi çeşidinde 138, Kirkit çeşidinde 168 ve Kabarcık çeşidinde 167 gün olarak belirlenmiştir (Çizelge 1).

İncelenen üzüm çeşitleri içerisinde en erken Kabarcık üzüm çeşidinin gözleri uyanmıştır (19 Nisan). Ancak ertesi gün diğer çeşitlerde de uyanma gerçekleşmiştir. Çeşitler haziran ayı içerisinde çiçeklenmişler ve ağustos ayı ortasından itibaren üzüm tanelerine ben düşmeye başlamıştır. Çeşitlerde ilk olgunlaşma Yalova İncisi çeşidinde 5 Eylül 2018 tarihinde gerçekleşmiştir. Bu tarihte söz konusu çeşidin olgunluk indisi 36.15 olarak hesaplanmıştır. Daha sonra diğer iki yerel çeşit olgunlaşmaya devam etmiştir. Ancak ekim ayı başında ortaya çıkan don tehlikesi riski nedeniyle bu çeşitler 5 Ekim 2018 tarihinde hasat edilmiştir. Bu tarihte Kirkit çeşidi tam olarak olgunlaşmasına karşın (olgunluk indisi: 34.03), Kabarcık çeşidinde olgunlaşma tam olarak gerçekleşmemiştir (olgunluk indisi: 14.24). $\mathrm{Bu}$ durum, son çeşidin tam olarak olgunlaşabilmesi için normal durumlarda biraz daha geç bir tarihte hasat edilmesi gerektiğini işaret etmektedir. 
Çeşitler arasında uyanma safhasının ilk başladığ 18 Nisan ile olgunlaşma safhasının gerçekleştiği son tarih olan 5 Ekim aralığında Göksun ilçesinde ortalama günlük hava sicaklığı değeri; en yüksek $25.7^{\circ} \mathrm{C}$, en düşük $5.7^{\circ} \mathrm{C}$ olarak ölçülmüştür. Aynı tarihler arasında maksimum sıcaklık $36.7^{\circ} \mathrm{C}$, minimum sıcaklık ise $-1.5^{\circ} \mathrm{C}$ olarak ölçülmüştür.

\section{2. Çeşitlere ait bazı pomolojik bulgular}

\subsubsection{Salkımların bazı kalite özellikleri}

İncelenen üzüm çeşitleri içerisinde en büyük salkımlar Kabarcık çeşidinde saptanmıştır (583.99 $\left.\mathrm{g} \mathrm{salkım}^{-1}\right)$. Çeşitlerin salkım eni, 9.20-15.17 cm arasında; salkım boyu ise 20.70$21.64 \mathrm{~cm}$ arasında değişmiştir (Çizelge 2).

\subsubsection{Tanelerde bazı kalite özellikleri}

Üzüm tanelerinin büyüklüğüyle ilgili özellikler Çizelge 3'de verilmiştir. Tane eni en yüksek, Yalova İncisi ve Kabarcık çeşitlerinde saptanmıştır (17.30 mm). Tane boyunun en yüksek olduğu üzüm çeşidi ise Yalova İncisi'dir $(22.87 \mathrm{~mm})$. Tane ağırlığı ise en yüksek Yalova İncisi çeşidinde saptanmıştır
(4.85 g). Bu durumda en iri taneler Yalova İncisi çeşidinde saptanmıştır.

Üzüm çeşitlerinin tane eti sertliği (TES), tanenin saptan ayrılma kuvveti (SAK) ve çekirdek sayısı (ÇS)'na ilişkin veriler Çizelge 4'de sunulmuştur. Kirkit çeşidi tane eti sertliği bakımından diğer çeşitlere göre daha yüksek değere sahip olmuştur $(2.91 \mathrm{~N})$. Üzüm tanelerinin saptan ayrılma kuvveti en düşük Yalova İncisi $(1.29 \mathrm{~N})$ ve en yüksek Kabarcık $(1.88 \mathrm{~N})$ çeşidinde tespit edilmiştir. Tanedeki çekirdek sayısı en az Kirkit çeşidinde saptanmıştır $\left(1.42\right.$ adet tane $\left.\mathrm{e}^{-1}\right)$.

\subsection{3. Şıra özellikleri}

Çeşitlerde yapılan analiz sonuçlarına göre en yüksek SÇKM $\% 22.8$ ile Kirkit çeşidinde, en düşük SÇKM değeri ise \%13.1 ile Kabarcık çeşidinde ölçülmüştür. Asitlik değerleri \%0.52 (Yalova İncisi) ile \%0.92 (Kabarcık) arasında değişmiştir. Çeşitlere ait üzüm şırasının $\mathrm{pH}$ değeri; en yüksek \%3.55 ile Yalova İncisinde; en düşük ise \%3.17 ile Kabarcık çeşidinde saptanmıştır Olgunluk indisi en yüksek 36.15 olarak Yalova İncisi'nde hesaplanmıştır (Çizelge 5).

Çizelge 1. Çeşitlere ait 2018 yılı içerisinde kaydedilen fenolojik safha tarihleri ve safhalar arasında geçen gün sayıları.

Table 1. Date of phenological stages and number of days between phenological stages for each cultivar in 2018.

\begin{tabular}{|c|c|c|c|c|c|c|c|c|}
\hline \multirow{2}{*}{ Çeşitler } & \multicolumn{4}{|c|}{ Fenolojik safha tarihleri } & \multicolumn{4}{|c|}{ Fenolojik safhalar arasındaki gün sayısı } \\
\hline & $\mathbf{U}^{*}$ & TÇ & BD $^{*}$ & $\mathbf{O}^{*}$ & $\mathbf{U}^{*}-\mathbf{T C}{ }^{*}$ & TÇ*-BD* & BD*-O* & $\mathbf{U}^{*}-\mathbf{O}^{*}$ \\
\hline Yalova İncisi & 20.04 & 15.06 & 15.08 & 05.09 & 56 & 61 & 21 & 138 \\
\hline Kirkit & 20.04 & 17.06 & 23.08 & 05.10 & 58 & 67 & 43 & 168 \\
\hline Kabarcık & 19.04 & 14.06 & 28.08 & 05.10 & 54 & 73 & 38 & 167 \\
\hline
\end{tabular}

*U: Uyanma; T.Ç. Tam Çiçeklenme; BD: Ben Düşme; O: Olgunluk

Çizelge 2. Çeşitlere ait salkımların fiziksel özellikleri.

Table 2. Cluster characteristics of grape cultivars.

\begin{tabular}{ccccc}
\hline Çeşitler & Salkım ağırlığı $\left(\mathbf{g ~ s a l k ı m}{ }^{-1}\right)$ & Salkım eni $(\mathbf{c m})$ & Salkım boyu $(\mathbf{c m})$ \\
\hline Yalova İncisi & $333.97 \pm 49.15$ & $9.20 \pm 1.35$ & $20.70 \pm 1.20$ \\
Kirkit & $422.40 \pm 150.87$ & $13.30 \pm 3.17$ & $21.40 \pm 2.04$ & Kalkım şekli \\
Kabarcık & $583.99 \pm 30.34$ & $15.17 \pm 1.89$ & $20.83 \pm 1.61$ & Konik \\
\hline
\end{tabular}

Çizelge 3. Üzüm tanelerinin bazı fiziksel özellikleri.

Table 3. Physical characteristics of grape berries.

\begin{tabular}{|c|c|c|c|c|}
\hline Çeşitler & Tane eni $(\mathrm{mm})$ & Tane boyu (mm) & Tane ağırlığı $\left(\right.$ g tane $\left.^{-1}\right)$ & Tane hacmi $\left(\mathrm{ml} \mathrm{tane}^{-1}\right)$ \\
\hline Yalova İncisi & $17.30 \pm 1.74$ & $22.87 \pm 2.18$ & $4.85 \pm 1.07$ & 4.4 \\
\hline Kirkit & $15.93 \pm 0.74$ & $19.99 \pm 0.93$ & $3.23 \pm 0.46$ & 2.8 \\
\hline Kabarcık & $17.30 \pm 1.03$ & $18.17 \pm 1.19$ & $3.21 \pm 0.60$ & 3.6 \\
\hline
\end{tabular}

Çizelge 4. Üzüm tanelerine ait bazı kalite özellikleri.

Table 4. Quality characteristics of grape berries.

\begin{tabular}{cccc}
\hline Çeşitler & TES $(\mathbf{N})$ & SAK $(\mathbf{N})$ & ÇS (Adet tane \\
\hline Yalova İncisi & $2.10 \pm 0.43$ & $1.29 \pm 0.57$ & $2.08 \pm 0.76$ \\
Kirkit & $2.91 \pm 0.49$ & $1.83 \pm 0.46$ & $1.42 \pm 0.58$ \\
Kabarcık & $1.66 \pm 0.39$ & $1.88 \pm 0.71$ & $2.64 \pm 0.86$ \\
\hline
\end{tabular}

Çizelge 5. Üzüm şıralarının hasat tarihindeki bazı biyokimyasal özellikleri.

Table 5. Biochemical characteristics of grape juices at harvest date.

\begin{tabular}{ccccc}
\hline Çeşitler & SÇKM (\%) & pH (\%) & Asitlik (\%) & Olgunluk İndisi \\
\hline Yalova İncisi & 18.8 & 3.55 & 0.52 & 36.15 \\
Kirkit & 22.8 & 3.45 & 0.67 & 34.03 \\
Kabarcık & 13.1 & 3.17 & 0.92 & 14.24 \\
\hline
\end{tabular}




\section{Tartışma ve Sonuç}

Üzümlerin son olarak hasat edildiği 5 Ekim 2018 tarihinde Kirkit çeşidinin olgunluk indisi 30'un üzerinde olarak tam olgunlaşmasına karşın, Kabarcık çeşidinde olgunluk indisinin 14.24'de kaldığı görülmüştür. Bu değer, sofralık üzümler için kabul edilen minimum olgunluk indisi değeri olan 20'nin altındadır (Karaçalı 2006). Oysa bu tarihte Kirkit çeşidi söz konusu minimum değerin üstünde olgunluk indisi değeri göstermiş ve olgunlaşmış kabul edilmiştir. Buna karş1lık, Kabarcık çeşidine ait salkımların henüz tam olarak olgunlaşamadığı kararına varılmıştır. Ekim ayı başında gece oluşan beklenmedik sonbahar erken don olayları nedeniyle Kabarcık çeşidi henüz tam olgunlaşamadan erken hasat edilmek zorunda kalınmıştır. Ekim ayının ilk haftası; yerel çeşitlerden Kirkit çeşidinin olgunluk indisi açısından hasat edilmeye uygun bir tarih olmasına karşın; Kabarcık çeşidi için erken bir tarihtir. Kabarcık çeşidinin hasadı için daha ileri tarihleri beklemek gerekir. Ancak bu durumda don riski de artacaktır. Bu gözlemler, Kabarcık çeşidinin ekim ayında oluşacak erken sonbahar donları nedeniyle Göksun için riskli olduğu, bunun yerine daha erken olgunlaşabilecek çok erkenci veya erkenci üzüm çeşitlerinin yörede tercih edilmesi gerektiği ortaya çıkmaktadır.

Yalova İncisi esas alınarak bu çeşidin başka yörelerdeki performansının Göksun'daki verileri ile karşılaştırıldığında bazı açılardan önemli farklılıklar görülmüştür. Aktürk (2017) tarafindan, Antalya'da Yalova İncisi için elde edilen veriler, Göksun'da elde edilen veriler ile karşılaştırıldığında; salkım ağırlığı Antalya'da 626 g saptanmasına karşın Göksun da $333.97 \mathrm{~g}$; tane ağırlığı Antalya'da $5.46 \mathrm{~g}$ olmasına karşın, Göksun'da $4.85 \mathrm{~g}$ olarak tespit edilmiştir. $\mathrm{Bu}$ durum, Göksun'daki bağ külleme hastalığından kısmen etkilenmiş olmasına karşın; Antalya'daki bağın düzenli sulama ve gübreleme koşullarında; T terbiye sisteminde ve hastalıssız bir şekilde daha iyi bakım koşullarında yetiştirilmiş olmasına yorumlanabilir. Bu çalışmada Yalova İncisi'nin, salkım ve tane ağırlığı konusunda elde edilen veriler, Gazioğlu Şensoy ve Balta (2010) ile Yücel (2009) tarafindan elde edilen veriler ile büyük oranda uyumludur. Aynı çeşit ile yapılan başka çalışmalarda elde edilen veriler arasındaki farklılıkların, ekolojilerin değişik olmasının yanı sıra, esas olarak yetiştirme koşullarından da kaynaklanabileceği düşünülmektedir. $\mathrm{Bu}$ nedenle çeşitlerin ekolojilere göre elde edilen verilerin karşılaştırılması yapılırken yetişme koşullarının da dikkate alınması gerekir. Göksun ilçesinde eylül ayında Yalova İncisi çeşidinin \%18.8'lik SÇKM değerine ulaşması, diğer erkenci çeşitlerin de bu bölgede rahatlıkla yetişebileceğinin bir kanıtıdır. Bu durum, Yalova İncisi'nin yanısıra, diğer çok erkenci uygun çeşitlerin seçilmesi durumunda; erken don riski olmasına karşın, söz konusu rakımdaki yerlerin güneşlenme ve sıcaklıklar açısından son turfanda bağcılık potansiyeline sahip olduğunu göstermektedir. Diğer taraftan, daha önce Yalınkılıç (1996) tarafından yapılan bir çalışmada, Göksun ilçesinde Kabarcığın 20 Eylül, Kirkit'in 30 Eylül tarihinde hasat edildiği belirtilmiştir. Söz konusu çalışmada rakım ve analiz yöntemi tam olarak belirtilmediği için verilere ihtiyatla yaklaşmak gerekmektedir. Ayrıca, Kabarcığın Kirkit'e göre 10 gün daha erken olgunlaşması da bu çalışma ile uyumlu değildir. İklimsel değişimden dolayı yıllara göre çeşitlerin olgunlaşma zamanlarında tarih bakımından farklılıklar olabilmesine karşın, çeşitlerin bu iklimsel değişime benzer tepki göstermesi ve çeşitlerin olgunlaşma sıralamasının pek değişmemesi gerekir.
Sonuç olarak, Göksun yöresinde yetiştirilen Kirkit yerel çeşidine ek olarak, Yalova İncisi gibi yeni erkenci üzüm çeşitlerinin başarılı bir şekilde yetiştirilebileceği saptanmıştır. Kabarcık çeşidinin yetiştiriciliği, yörede ekim ayı başında oluşan don olayları nedeniyle risklidir. Yalova İncisi gibi erkenci bir çeşidin yüksek bir rakımda başarılı sonuçlar vermesi son turfanda bağcıllı açısından yörede diğer erkenci çeşitler ile bağ tesis edilerek erkenci çeşitlerin yöreye adaptasyonlarının incelenmesi gerektiğini ortaya koymaktadır. Bu açıdan, yörede Early Sweet gibi çok erkenci, Trakya İlkeren, Prima, Victoria, Black Magic, Superior Seedless gibi diğer çok erkenci çeşitler ile bağ kurulmasında yarar vardır. Yeni seçilecek çeşitler arasında, çekirdekli veya çekirdeksiz; siyah veya beyaz taneli gibi olanlar seçilerek ve değişik çeşit kombinasyonları uygulanarak, tüketicilerin farklı üzüm tercihleri de karşılanabilir. Ayrıca, yüksek rakımlı yörelerde, erkenci çeşitlerin de kendi arasında kombinasyonu ile çeşit bazında üretim planlaması yapılarak yöre çiftçisine alternatif bir geçim kaynağı sunulabilir.

\section{Teşekkür}

$\mathrm{Bu}$ projenin gerçekleştirilmesine parasal katkı sağlayan Akdeniz Üniversitesi Rektörlüğü Bilimsel Araştırma Projeleri Koordinasyon Birimi (Proje no: FYL-2018-2473) ile üzüm analizlerinin yapılmasında katkı sağlayan Burak Aktürk'e ve Göksun ilçesinde bağcılık yapan Oktay Ayar'a teşekkürlerimizi sunarı.

\section{Kaynaklar}

Ağaoğlu YS (2002) Bilimsel ve Uygulamalı Bağcılık, Cilt II, Asma Fizyolojisi (I). Kavaklıdere Eğitim Yayınları No: 5, Ankara, s. 445.

Aktürk B (2017) Bazı üzüm çeşitlerinin Antalya ekolojisindeki fenolojik safha tarihleri, etkili sıcaklık toplamları ve yörelere uygunlukları üzerine araştırmalar. Yüksek Lisans tezi. Akdeniz Üniversitesi, Antalya, s. 62.

Cemeroğlu B (2010) Gıda Analizleri, Gıda Teknolojisi Dergisi Yayınları No:34, Ankara, s. 657.

Gazioğlu Şensoy R, Balta F (2010) Bazı üzüm çeşitlerinin Van ekolojik şartlarına adaptasyonu. Yüzüncü Yıl Üniversitesi Tarım Bilimleri Dergisi 20(3): 159-170.

Gürsöz S, Ergenoğlu F (1987) Adana koşullarında yetiştirilen 16 üzüm çeşidinin bazı fenolojik ve kimyasal değerleri üzerinde bir araştırma. Çukurova Üniversitesi Fen Bilimleri Enstitüsü, Fen ve Mühendislik Bilimleri Dergisi I(2): 29-38.

Karaçalı İ (2006) Bahçe Ürünlerinin Muhafaza ve Pazarlanması. 5. Baskı. Ege Üniversitesi Ziraat Fakültesi Yayınları No: 494, İzmir, s. 481.

Kıraç AM (2016) Kısıntılı ve kısmi kök kuruluğu sulama tekniklerine MM 106 anaçlı "Red Chief" elma çeşidinin tepkilerinin belirlenmesi. Doktora tezi, Sütçü İmam Üniversitesi Fen Bilimleri Enstitüsü, Kahramanmaraş.

OIV (2001) $2^{\text {nd }}$ Edition of the OIV descriptor list for grape varieties and vitis species. Paris, pp. 232.

Uzun Hİ, Barış C, Gürnil K, Özışık S (1995) Bazı yeni üzüm çeşitlerinin Antalya koşullarına adaptasyonu üzerine araştırmalar. Akdeniz Üniversitesi Ziraat Fakültesi Dergisi 8: 65-80.

Uzun Hİ (2004) Bağcılık El Kitabı. Hasad Yayıncılık, s. 156. 
Yalınkılıç A (1996) Kahramanmaraş ili bağcılığı, üzüm çeşitlerinin fenolojik gelişimleri ve ümitvar görülen bazılarında göz verimliliklerinin saptanması üzerinde bir araştırma. Yüksek Lisans tezi, Kahramanmaraş Sütçü İmam Üniversitesi, Kahramanmaraş, s. 23.
Yücel E (2009) Ceyhan ilçesi bağ alanlarının uzaktan algılama sistemleri kullanılarak saptanması ve üzüm çeşitlerinin fenolojik ve pomolojik özelliklerinin incelenmesi. Yüksek Lisans Tezi. Çukurova Üniversitesi, Adana, s. 66. 